\title{
PENGARUH KEPUASAN GAJI, PENGEMBANGAN KARIR GURU TERHADAP KOMITMEN ORGANISASI DENGAN KEPUASAN KERJA SEBAGAI PENGUBAH PENGANTARA
}

\author{
Suryatiningsih \\ Magister Manajemen, Universitas Bunda Mulia \\ Alamat surel: curyaismara@gmail.com \\ Tonny Hendratono \\ Universitas Bunda Mulia \\ Alamat surel: tonny.hendratono@yahoo.com
}

\begin{abstract}
This study is aimed to determine the effect of satisfaction Salary (X1) and Career Development (X2), on Job Satisfaction (Y1) and Organizational Commitment (Y2) in private junior high school teacher (SMP) in the city of Tangerang. The reason underlying this study is the emergence of research problems that is the decreasing of the number of teachers, while at the same time there is the increasing of the amount of school, thus increasing the teacher-student ratio in Tangerang of in the period 2009 to 2011. These problems indicate the declining job satisfaction of teachers, and as the impact the teachers commitments become low in private Junior High School (SMP) in the city of Tangerang organization. The results of Confirmatory Factor Analysis (CFA) of the variables in this research show good evidence. While the results of the analysis of Goodness of Fit shows mostly match with the standard indicator models, so it can be concluded that the studies conducted have good Goodness of Fit and acceptable models.Hypothesis testing results show: (1) pay satisfaction significantly and positively affect the commitment of the organization; (2) pay satisfaction significantly affects and positivly impact on job satisfaction; (3) career development does not affect significantly and negatively on the commitment to the organization; (4) career development significantly and positively influence on job satisfaction; and (5) job satisfaction affects significantly and positively to the commitment to the organization.

Future research is expected to develop an existing model by adding variables that affect the commitment to the organization, such as work environment, leadership style, organizational climate, motivation and organizational culture. It can also be developed by comparing between teachers in private school and in the state school.
\end{abstract}

Keywords: Pay, Career Development, Job Satisfaction and Commitment.

\begin{abstract}
Abstrak
Penelitian ini bertujuan untuk mengetahui pengaruh dari Kepuasan Gaji (X1) dan Pengembangan Karir (X2), terhadap Kepuasan Kerja (Y1) dan Komitmen pada Organisasi (Y2) pada guru Sekolah Menengah Pertama (SMP) swasta di kota Tangerang. Alasan yang mendasari penelitian ini yaitu munculnya research problem yakni penurunan jumlah guru, padahal disaat yang bersamaan terjadi penambahan jumlah sekolah, sehingga meningkatkan rasio guru-murid di kota Tangerang pada periode 2009 sampai dengan 2011. Permasalahan tersebut menunjukkan menurunnya kepuasan kerja yang berdampak rendahnya komitmen guru Sekolah Menengah Pertama (SMP) swasta di kota Tangerang pada organisasinya. Data yang digunakan adalah data primer dan data sekunder yang diperoleh melalui kuesioner, literatur, jurnal, dan sumber-sumber yang mendukung. Sampel dalam penelitian ini sejumlah 155 responden dengan menggunakan metode Simple Random Sampling. Analisis data menggunakan SEM dengan program Lisrel versi 8.80. Hasil Confirmatory Factor Analysis (CFA) dari peubah-peubah yang dilakukan dalam penelitian ini menunjukkan bukti baik. Sedangkan hasil analisa Goodness of Fit menunjukkan sebagian besar uji kelayakan model sesuai dengan indikator standar kecocokan, sehingga dapat disimpulkan bahwa penelitian yang dilakukan mempunyai Goodness of Fit baik dan model dapat diterima. Hasil pengujian hipotesis menunjukkan: (1) kepuasan gaji mempengaruhi secara signifikan dan positif terhadap komitmen pada organisasi; (2) kepuasan gaji mempengaruhi secara signifikan dan positif terhadap kepuasan kerja; (3) pengembangan karir tidak mempengaruhi secara signifikan dan negatif terhadap komitmen pada organisasi; (4) pengembangan karir mempengaruhi secara signifikan dan positif terhadap kepuasan kerja; dan (5) kepuasan kerja mempengaruhi secara signifikan dan positif terhadap komitmen pada organisasi.
\end{abstract}

Kata Kunci: Gaji, Pengembangan Karir, Kepuasan Kerja, Komitmen. 


\section{PENDAHULUAN}

\section{Latar Belakang}

Pendidikan merupakan salah satu aspek penting dalam kehidupan dan merupakan kebutuhan dasar setiap manusia. Kesempatan pendidikan yang merata sangat dipengaruhi oleh tersedianya sarana dan prasarana pendidikan seperti gedung sekolah, perpustakaan, buku-buku penunjang dan tenaga pendidik (guru). Fasilitas pendidikan di Kota Tangerang tersedia dari tingkat Taman Kanak-Kanak (TK) sampai Perguruan Tinggi. Berikut data jumlah Sekolah tingkat pendidikan dasar dan menengah di Kota Tangerang antara tahun 2009 sampai dengan 2012 (KTDA 2012 Badan Pusat Statistik / BPS):

Tabel 1. Jumlah Sekolah tingkat pendidikan dasar dan menengah berdasarkan statusnya di Kota Tangerang

\begin{tabular}{|c|c|c|c|c|c|c|c|c|}
\hline Tahun & \multicolumn{2}{|c|}{ SD } & \multicolumn{2}{c|}{ SMP } & \multicolumn{2}{c|}{ SMA } & \multicolumn{2}{c|}{ SMK } \\
\cline { 2 - 9 } Pelajaran & Negeri & Swasta & Negeri & Swasta & Negeri & Swasta & Negeri & Swasta \\
\hline \hline $2009 / 2010$ & 376 & 119 & 24 & 149 & 15 & 72 & 7 & 89 \\
\hline $2010 / 2011$ & 378 & 126 & 24 & 152 & 15 & 72 & 7 & 91 \\
\hline $2011 / 2012$ & 378 & 126 & 26 & 156 & 15 & 74 & 9 & 92 \\
\hline \hline $\begin{array}{c}\text { Persentase } \\
\text { peningkatan }\end{array}$ & $0,40 \%$ & $1,41 \%$ & $1,16 \%$ & $4,04 \%$ & $0 \%$ & $2,29 \%$ & $2,19 \%$ & $3,13 \%$ \\
\hline
\end{tabular}

Sumber: KTDA 2012, BPS Kota Tangerang

Data tersebut menunjukkan terjadi peningkatan jumlah Sekolah antara tahun 2009 sampai dengan 2012. Persentase peningkatan yang paling tinggi selama tiga tahun terakhir tersebut adalah Sekolah Menengah Pertama (SMP) Swasta di Kota Tangerang yakni sebesar 4,04\%.

Guru merupakan aset dari organisasi sekolah yang paling penting sehingga harus di kelola dengan baik, karena mereka memegang peranan penting dalam membentuk dan mencapai tujuan organisasi. Hal ini didukung pendapat Hasibuan (2009) yang menyatakan bahwa manusia selalu berperan aktif dan dominan dalam setiap organisasi. Berikut adalah data jumlah guru Sekolah Menengah Pertama (SMP) Swasta tahun pelajaran 2009/2010 sampai dengan 2011/2012 (Badan Pusat Statistik / BPS Kota Tangerang) seperti terlihat pada tabel 2.

Tabel 2. Jumlah Guru Sekolah Menengah Pertama (SMP) berdasarkan statusnya di Kota Tangerang

\begin{tabular}{|c|c|c|c|}
\hline \multirow{2}{*}{ Tahun Pelajaran } & \multicolumn{2}{|c|}{ Jumlah Guru } & \multirow{2}{*}{ Jumlah Total } \\
\cline { 2 - 3 } & SMP Negeri & SMP Swasta & \\
\hline $2009 / 2010$ & 432 & 2.954 & 3.386 \\
\hline $2010 / 2011$ & 432 & 2.847 & 3.306 \\
\hline $2011 / 2012$ & 490 & 2.789 & 3.279 \\
\hline
\end{tabular}

Sumber: KTDA 2012, BPS Kota Tangerang 
Sehubungan dengan hal tersebut, dapat dihitung rasio antara jumlah guru dan siswa di Sekolah Menengah Pertama (SMP) Swasta Kota Tangerang. Berdasarkan Badan
Pusat Statistik (BPS) Kota Tangerang data rasio jumlah guru dan murid Sekolah Menengah Pertama (SMP) Swasta Kota Tangerang dapat dilihat di Tabel 3.

Tabel 3. Rasio jumlah guru dan murid SMP swastadi Kota Tangerang

\begin{tabular}{|c|c|}
\hline Tahun Pelajaran & Rasio Murid Guru \\
\hline $2009 / 2010$ & 18,03 \\
\hline $2010 / 2011$ & 20,60 \\
\hline $2011 / 2012$ & 21,86 \\
\hline
\end{tabular}

Sumber: KTDA 2012, BPS Kota Tangerang

Guru merupakan Sumber Daya Manusia (SDM) yang sangat penting di suatu sekolah. Guru harus berkualitas dan memiliki kepuasan kerja yang tinggi agar dapat bekerja dengan optimal. Sehubungan itu Dessler (2005:99) menjelaskan kepuasan kerja (Job Satisfaction) sebagai perasaan positif tentang pekerjaan seseorang yang merupakan hasil dari sebuah evaluasi karakteristiknya. Seorang dengan tingkat kepuasan kerja tinggi akan memiliki perasaan positif terhadap pekerjaannya, sementara seorang yang tidak puas memiliki perasaan negatif terhadap pekerjaannya.

Kepuasan kerja tinggi maka akan meningkatkan komitmen pada organisasinya. Luthans (2006) mengartikan komitmen pada organisasi merupakan sikap yang menunjukkan kesetiaan karyawan dan merupakan proses berkelanjutan bagaimana anggota organisasi ungkap perhatian mereka pada keberhasilan dan kebaikan organisasinya. Secara spesifik menurut Luthans (2006), sikap setia karyawan ini ditunjukkan oleh tiga hal, yaitu (1) keinginan kuat seseorang untuk tetap menjadi anggota organisasinya, (2) kemauan untuk mengerahkan usaha untuk organisasinya, dan (3) keyakinan dan penerimaan terhadap nilai-nilai dan tujuan organisasi.

Penelitian tentang pengaruh antara kepuasan kerja dan komitmen pada organisasi mempunyai hasil yang beragam. Masalah yang akan diteliti adalah adanya celah penelitian dari penelitian sebelumnya. Dari berbagai penelitian yang ada, keterhubungan antara kepuasan kerja dan komitmen pada organisasional tidak konsisten. Sebagian penelitian menganggap ada pengaruh positif antara kepuasan kerja dan komitmen pada organisasi, sebagaimana studi yang dilakukan oleh Chunghtai \& Zafar (2006) yang mendapatkan pengaruh positif antara kepuasan kerja dengan komitmen pada organisasi di sektor perbankan. Jika karyawan puas dengan pekerjaannya, rekan kerja, pembayaran, dan atasannya, dan kepuasan kerja keseluruhan, mereka lebih berkomitmen pada organisasi (Okpara, 2004 ; Mathur\& Salunke, 2013).

Pandangan lain menyatakan tidak ada pengaruh antara kepuasan kerja dan komitmen pada organisasi. Curry et al., (1986) menemukan bahwa tidak ada pengaruh yang signifikan antara kepuasan kerja dan komitmen pada organisasi.

Penelitian ini dilakukan berdasarkan adanya dua alasan yaitu: (1) adanya celah penelitian yang telah diungkapkan dalam uraian sebelumnya, (2) adanya masalah penelitian yang ditemukan dilapangan. Penelitian ini dilakukan pada Sekolah Menengah Pertama (SMP) Swasta di Kota Tangerang. Penelitian ini menggunakan peubah-peubah kepuasan gaji, pengembangan karir, kepuasan kerja dan komitmen pada organisasi. Penelitian ini bertujuan mengetahui pengaruh kepuasan gaji, pengembangan karir dan kepuasan kerja terhadap komitmen pada organisasi para guru Sekolah Menengah Pertama (SMP) Swasta di Kota Tangerang.

\section{Masalah Penelitian}

Agar kepuasan karyawan meningkat, maka organisasi senantiasa harus memperhatikan hal-hal yang dapat 
memengaruhi kemampuan seseorang dalam menjalankan pekerjaannya. Kepuasan kerja dapat mengakibatkan pengaruh terhadap tingkat turn over, dan tingkat absensi terhadap kesehatan fisik dan mental serta tingkat kelambanan. Menurut Okpara (2004), faktor-faktor yang memengaruhi kepuasan kerja adalah pekerjaannya, rekan kerja, dan penyeliaan. Travis, (2004) menemukan kepuasan kerja dipengaruhi oleh kepuasan gaji dan situasi kerja sehingga akan meningkatkan kinerja karyawan. Jika karyawan puas dengan pekerjaannya, rekan kerja, pembayaran, dan atasannya, dan kepuasan kerja keseluruhan, mereka lebih berkomitmen pada organisasi (Okpara, 2004; Mathur\& Salunke, 2013).

Berdasarkan uraian di atas, maka masalah penelitian adalah sebagai berikut:

1. Apakah ada pengaruh kepuasan gaji terhadap komitmen pada organisasi?

2. Apakah ada pengaruh kepuasan gaji terhadap kepuasan kerja?

3. Apakah ada pengaruh pengembangan karir terhadap komitmen pada organisasi?

4. Apakah ada pengaruh pengembangan karir terhadap kepuasan kerja?

5. Apakah ada pengaruh kepuasan kerja terhadap komitmen pada organisasi?

\section{Tujuan Penelitian}

Berdasarkan paparan diatas, bahwa meningkatnya jumlah SMP swasta di kota Tangerang harus diimbangi dengan jumlah guru yang memadai. Agar dapat memberikan layanan pendidikan yang berkualitas, maka sekolah harus mampu membangun kepuasan kerja guru melalui kepuasan gaji dan pengembangan karir, sehingga dapat meningkatkan komitmen pada organisasi guru SMP swasta kota Tangerang.

Tujuan umum penelitian ini adalah untuk mengetahui pengaruh kepuasan gaji, pengembangan karir dan kepuasan kerja terhadap komitmen pada organisasi guru
Sekolah Menengah Pertama (SMP) Swasta di Kota Tangerang.

\section{TELAAH PUSTAKA}

\section{Komitmen pada Organisasi}

Meyer dan Allen

merumuskan suatu definisi mengenai komitmen dalam berorganisasi adalah suatu konstruk psikologis yang merupakan karakteristik hubungan anggota organisasi dengan organisasinya dan memiliki implikasi terhadap keputusan individu untuk melanjutkan keanggotaannya dalam berorganisasi.Muthuveloo dan Rose (2005) mendefinisikan komitmen organisasi sebagai tingkat keterlibatan pekerja dengan organisasinya. Komitmen organisasi dapat dikaitkan sebagai kesetiaan karyawan terhadap organisasi dan menjadi bagian dari organisasi tersebut.

$$
\text { Mowday et al., }
$$

mendefinisikan komitmen pada organisasi sebagai kekuatan relatif dari identifikasi individu dan keterlibatan dalam organisasi khusus, meliputi kepercayaan, dukungan terhadap tujuan dan nilai organisasi, dan keinginan yang kuat untuk menggunakan upaya yang sungguh-sungguh untuk kepentingan organisasi, dan kemauan yang kuat untuk memelihara keanggotaan dalam organisasi. Menurut Mobley (2006:21) komitmen pada organisasi didefinisikan sebagai tingkat kekerapan identifikasi dan tingkat keterikatan individu kepada organisasi tertentu yang dicerminkan dengan karakteristik: adanya keyakinan yang kuat dan penerimaan atas nilai dan tujuan organisasi dan adanya keinginan yang pasti untuk mempertahankan keikutsertakan dalam organisasi.

\section{Kepuasan Gaji}

Gaji menurut Heery \& Noon (2001) adalah pembayaran yang diterima oleh karyawan yang meliputi gaji pokok, manfaat, bonus, upah diluar jam kerja dan insentif. Bagi pekerja, gaji dipandang sebagai suatu capaian atau imbalan yang penting. Menurut Lum et al., (1998) bahwa individu akan merasakan keadilan (equity) terhadap gaji yang diterima sehubungan dengan pekerjaan yang dilakukannya. 
Heneman \& Schwab (1985) menyatakan bahwa kepuasan atas gaji merupakan konstruk yang multi dimensi yang terdiri dari empat subdimensi, yaitu tingkat gaji (pay level), struktur/pengelolaan gaji (pay structure/administration), peningkatan gaji (pay raise), dan tunjangan (benefit).

\section{Pengembangan Karir}

Dessler (2005) menerjemahkan karir sebagai pekerjaan yang dimiliki seseorang selama bertahun-tahun. Karir dapat menggambarkan kedudukan seorang individu, serta menunjukkan perkembangan dan keberhasilan karyawan dalam pekerjaan diorganisasinya, (De Simone, Harris, 2001:345).

Pengembangan karir menurut Dessler (2005) adalah serangkaian aktifitas sepanjang hidup (seperti workshop) yang berkontribusi pada eksplorasi, pemantapan, keberhasilan dan pemenuhan karir seseorang. Pengembangan karir dalam sebuah organisasi membutuhkan suatu pemeriksaan atas dua proses, yaitu bagaimana masing-masing individu merencanakan dan menerapkan tujuan karir (perencanaan karir) dan bagaimana organisasi merancang dan menerapkan program pengembangan karir atau manajemen karir (Labbase, 2010).

\section{Kepuasan Kerja}

Robbins, (2006) menyatakan bahwa kepuasan kerja sebagai suatu perasaan positif tentang pekerjaan seseorang yang merupakan hasil dari sebuah evaluasi karakteristiknya. Kepuasan kerja adalah atribut yang sangat penting yang sering diukur oleh organisasi dan cara pengukuran yang paling umum adalah penggunaan skala penilaian karyawan terhadap pekerjaan mereka (Judge, et al:2001).

Selanjutnya Kreitner \& Kinicki (2005: 169) menulis bahwa kepuasan kerja sebagai efektivitas atau tanggapan emosional terhadap berbagai aspek pekerjaan. Tidak berbeda dengan berbagai pendapat tersebut, Luthans (2006) menyatakan bahwa kepuasan kerja adalah perasaan pekerja atau karyawan yang berhubungan dengan pekerjaannya, yaitu merasa senang atau tidak senang, sebagai hasil penilaian individu yang bersangkutan terhadap pekerjaannya.

\section{METODE}

\section{Model Penelitian}

Penelitian oleh Azeem (2010) terhadap para pekerja di Pemerintahan Oman juga menunjukkan hasil bahwa kepuasan gaji merupakan prediktor yang signifikan atas komitmen pada organisasi. Hal ini menunjukkan bahwa kepuasan gaji merupakan prediktor komitmen pada organisasi. Sebagaimana penelitian Jones \& Sloane (2007) bahwa aras gaji memengaruhi kepuasan kerja karyawan. Trochim (2006) juga menerangkan bahwa kepuasan gaji merupakan salah satu faktor yang memengaruhi kepusan kerja. Sebagaimana Heneman et al. (1985), kepuasan gaji merupakan konstruk yang multidimensi yang terdiri atas empat subdimensi: tingkat gaji (pay level), struktur/pengelolaan gaji (pay structure/administration), peningkatan gaji (pay raise), dan tunjangan (benefit).

Penelitian dari Chang (1999) menemukan bahwa komitmen karir memiliki pengaruh yang signifikan terhadap komitmen organisasi,sedangkan Goulet dan Singh (2002) menemukan bahwa komitmen organisasi adalah signifikan sebagai penentu komitmen karir. Weng et al., (2010), melakukan penelitian yang menguji pengaruh antara pertumbuhan karir karyawan dan komitmen organisasi.

Okpara (2004) menjelaskan bahwa ada pengaruh positif antara kepuasan kerja dan komitmen organisasi. Penelitian ini menyatakan bahwa jika karyawan puas dengan pekerjaan mereka, rekan kerja, dan pengawasan di industri, maka mereka berkomitmen pada organisasinya. Dalam penelitian yang dilakukan oleh Chiun-Lo dan Ramayah (2011), didapatkan bahwa dengan dilakukan mentoring yang baik pada pekerjaan itu sendiri, promosi, penyeliaan pimpinan, dan kelompok kerja akan menimbulkan kepuasan kerja dan kepercayaan diri dari karyawan tersebut. Berdasarkan uraian di atas, maka disusunlah hipotesis-hipotesis yang memperlihatkan kaitan antara peubah-peubah. 


\section{Hipotesis Penelitian}

Penelitian Abdullah \& Ramay (2012) menunjukkan bahwa kepuasan gaji memiliki korelasi dengan komitmen pada organisasi. Penelitian serupa yang dilakukan oleh Azeem (2010) menunjukkan hasil bahwa kepuasan gaji merupakan prediktor yang signifikan atas komitmen pada organisasi. Sebagaimana hasil penelitianVanderberghe dan Trembley (2008) mengindikasikan bahwa kepuasan gaji sama-sama menunjukkan pengaruh yang positif dan signifikan terhadap komitmen pada organisasi. Berdasarkan uraian diatas, maka hipotesis yang diajukan dalam penelitian ini adalah:

\section{H1: Kepuasan Gaji memengaruhi secara positif terhadap Komitmen pada Organisasi}

Menurut Lum et al., (1998) kepuasan gaji dapat diartikan bahwa seseorang akan terpuaskan dengan gajinya ketika persepsi terhadap gaji dan apa yang mereka peroleh sesuai dengan yang diharapkan. Penelitian Judge et al., (2010) melakukan meta-analisis menunjukkan bahwa gaji berkorelasi dengan tingkat kepuasan karyawan. Sebagaimana Bartol dan Liu (2005) menunjukkan bahwa tingkat gaji dan kenaikan gaji mempunyai pengaruh terhadap kepuasan kerja karyawan. Temuan empiris penelitian Nizaret al., (2012) menunjukkan pengaruh positif antara kepuasan gaji dan kepuasan kerja. Penelitian Al-Zoubi (2012) menunjukkan bahwa peningkatan kepuasan kerja dengan cara meningkatkan gaji dan tunjangan keuangan. Berdasarkan uraian diatas, maka hipotesis yang diajukan dalam penelitian ini adalah:

\section{H2: Kepuasan Gaji memengaruhi secara positif terhadap Kepuasan Kerja}

Ogaboh et al., (2010) yang menguji pengaruh antara pengembangan karir dan komitmen karyawan menunjukkan bahwa, kemajuan karir, konseling karir dan peluang karir secara signifikan memengaruhi komitmen pekerja. Hasil yang ditemukan Riveros\& Tsai (2011), memperlihatkan bahwa peubah komitmen karir mungkin memengaruhi komitmen organisasi dan sebaliknya. Penelitian Adio \& Popoola
(2009) menunjukkan bahwa tenaga kerja yang puas terhadap suasana dan kebijakan karir organisasi akan berfokus pada karir serta bekerja secara professional dan tidak akan berpikir untuk keluar dari pekerjaannya.Hasil penelitian Bashir \&Ramay (2008) menunjukkan bahwa peluang karir dan kehidupan kerja, kebijakan profesional IT secara signifikan berkorelasi dengan komitmen organisasi, sedangkan karakteristik pekerjaan tidak menentukan komitmen organisasi mereka. Berdasarkan uraian diatas, maka hipotesis yang diajukan dalam penelitian ini adalah:

\section{H3: Pengembangan Karir memengaruhi secara positif terhadap Komitmen pada Organisasi}

Penelitian Kalayar et al., (2009) bertujuan untuk menyelidiki pengaruh antara perencanaan karir individu dan kepuasan kerja untuk dua jenis pekerja universitas yakni staf akademik dan administrasi. Hasilnya menunjukkan bahwa sebuah rencana karir akan membantu karyawan merasa nyaman dalam pekerjaannya dan secara langsung akan memengaruhi kepuasan kerja. Sebagaimana Shujaat et al., (2013) hasil penelitian ini menetapkan bahwa terdapat keterhubungan positif antara pengembangan karir dan kepuasan kerja karyawan di sektor perbankan. Karyawan puas dengan kegiatan pengembangan karir yang ditawarkan di organisasi mereka. Berdasarkan uraian diatas, maka hipotesis yang diajukan dalam penelitian ini adalah:

\section{H4: Pengembangan Karir memengaruhi secara positif terhadap Kepuasan Kerja}

Naderi (2012) menyatakan adanya keterhubungan positif yang signifikan antara kepuasan kerja dan komitmen organisasi. Sebagaimana penelitian Abdullah dan Ramay (2012) menunjukkan bahwa karakteristik pribadi, aspek kepuasan kerja dan persepsi terhadap keadilan keorganisasian secara positif dan signifikan pengaruh dengan komitmen pada organisasi. Keterhubungan yang positif antara kepuasan kerja dan komitmen pada organisasi dilakukan oleh Mathur \& Salunke (2013). Mohamadkhani et al., (2012) telah 
menyimpulkan bahwa karyawan yang puas akan lebih berkomitmen dalam organisasi pada industri hotel. Penelitian Nguyen et al., (2014) menunjukkan bahwa kepuasan kerja sebagai jalur untuk menentukan komitmen organisasi. Berdasarkan uraian diatas, maka hipotesis yang diajukan dalam penelitian ini adalah:
H5: Kepuasan Kerja memengaruhi secara positif terhadap Komitmen Organisasi

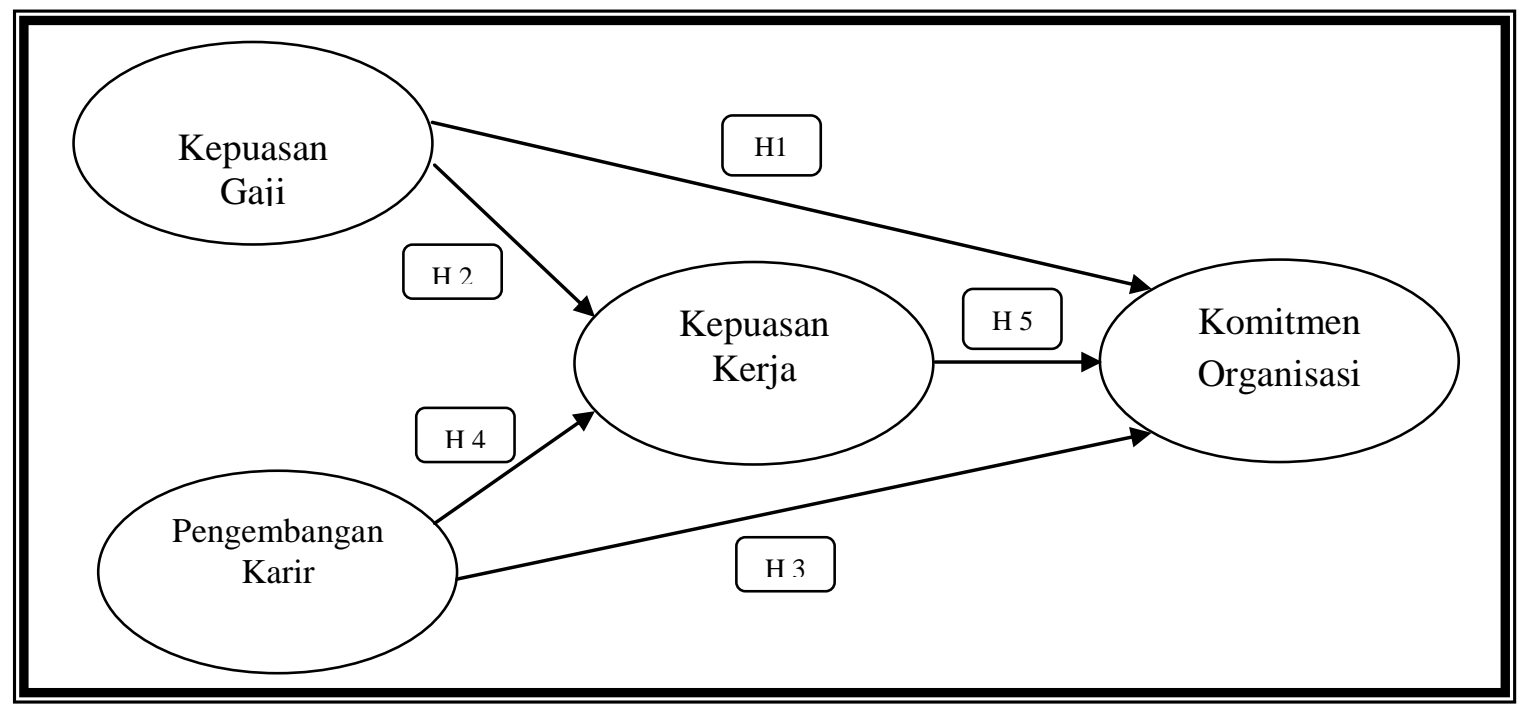

Sumber: Model yang dikembangkan dalam penelitian ini Gambar 1. Model Teoritis

\section{METODE PENELITIAN}

Populasi dalam penelitian ini adalah Guru Sekolah Menengah Pertama (SMP) swasta di Kota Tangerang, dengan rincian sebagai berikut:

Tabel 4. Jumlah Guru SMP Swasta Kota Tangerang Tahun 2009 - 2011

\begin{tabular}{|c|c|}
\hline Tahun Pelajaran & Jumlah Guru \\
\hline $2009 / 2010$ & 2.954 \\
\hline $2010 / 2011$ & 2.847 \\
\hline $2011 / 2012$ & 2.789 \\
\hline
\end{tabular}

Sumber: Badan Pusat Statistik Kota Tangerang, 2012

Menurut Hair et al., (2010), ukuran sampel yang sesuai untuk digunakan dalam penelitian adalah antara $100 \mathrm{~s} / \mathrm{d} 200$. Oleh karena itu, Hair et al., (2010) merekomendasikan jumlah sampel yang sesuai berkisar antara 100 sampai 200, atau sebanyak lima sampel minimal dari setiap indikator, jadi 27 indikator x $5=135$.

Teknik pembentukan yang digunakan adalah dengan menggunakan metode sampling non probability. Data dikumpulkan dengan menggunakan angket yaitu dengan mengajukan pernyataanpernyataan dalam angket dibuat menggunakan skala Likert dengan skor 1 - 6 untuk memperoleh data yang bersifat interval.

Uji kesahihan dilakukan dengan tujuan mengetahui ketepatan indikator yang mempunyai arti bahwa indikator mampu mengukur apa yang seharusnya diukur. Perhitungan koefisien kesahihan konstruk ini 
dilakukan dengan analisis faktor konfirmatori (Confirmatory Factor Analysis / CFA). Uji kehandalan bertujuan untuk mengetahui seberapa jauh sebuah alat ukur dapat dihandalkan atau dipercaya. Untuk menguji kehandalan konstruk dilakukan perhitungan nilai construct reliability dan variance extracted dari masing-masing peubah. Kehandalan peubah dinyatakan baik, jika nilai construct reliability $\geq 0,70$ dan nilai variance extracted $\geq 0,50$ (Hair et. al., 2010).

Untuk menguji pernyataan dalam kuesioner, maka dilakukan pra-uji kepada 30 responden yang sesuai dengan syarat sampel penelitian. Setelah dilakukan pre-uji, kuisioner dikirim ke responden. Kuisioner yang telah diisi lengkap dianalisis dengan model persamaan struktural (Structural Equation Modelling) yang dioperasikan melalui program LISREL (Linear Structural Relationship) versi 8.80. Penggunaan prosedur analisis dengan SEM (Structural Equation Modelling) menurut Bollen dan Long (Latan: 2013) terdiri dari lima tahap yaitu: (1) spesifikasi model (model specification), (2) identifikasi (identification), (3) estimasi (estimation), (4) uji kecocokan (testing fit), dan (5) respesifikasi (re-specification).

\section{Hasil Penelitian}

Responden dalam penelitian ini adalah para guru SMP swasta di Kota Tangerang. Untuk mengetahui pengaruh kepuasan gaji, pengembangan karir dan kepuasan kerja terhadap komitmen pada organisasi, maka disebarkan 170 eksemplar kuisioner yang diberikan kepada para guru SMP swasta yang berstatus sebagai Guru Tetap Yayasan (GTY) di Kota Tangerang. Kuisioner yang kembali sejumlah 158 eksemplar $(92,94 \%)$. Dari kuisioner tersebut sejumlah 3 eksemplar tidak diisi dengan lengkap, sehingga kuisioner yang dapat dianalisis lebih lanjut sejumlah 155 eksemplar. Kelompok umur 26 - 35 tahun sebesar 36,77\%, umur 36- 45 tahun sebesar $29,03 \%$, umur 46 - 55 tahun sebesar $18,71 \%$ dan persentasi terkecil terletak pada kelompok umur 56 - 60 tahun sebesar $2,58 \%$. Sebagian besar perempuan yakni sebesar 54,86\%, sedangkan laki-laki yakni sebesar 45,14\%. Pendidikan S1 yaitu sebesar $89,68 \%$, sedangkan responden yang memiliki tingkat pendidikan Diploma sebesar 5,81\% dan S2 sebesar 4,52\%. Status pernikahan responden adalah $75,48 \%$ sudah menikah, dan $24,52 \%$ belum menikah.

Statistik deskriptif berupa nilai minimum, nilai maksimum, nilai rata-rata dan nilai standar deviasi dari jawaban masing-masing indikator adalah sebagai berikut:

Tabel 5. Kepuasan Gaji

\begin{tabular}{|c|c|c|c|c|}
\hline Indikator & Nilai Minimum & $\begin{array}{c}\text { Nilai } \\
\text { Maksimum }\end{array}$ & $\begin{array}{c}\text { Nilai } \\
\text { Rata-rata }\end{array}$ & Standar Deviasi \\
\hline $\mathrm{KG}_{1}$ & 1 & 6 & 3.968 & 1.245 \\
\hline $\mathrm{KG}_{2}$ & 1 & 6 & 4.561 & 1.185 \\
\hline $\mathrm{KG}_{3}$ & 1 & 6 & 4.490 & 1.059 \\
\hline $\mathrm{KG}_{4}$ & 1 & 6 & 4.561 & 0.994 \\
\hline \multicolumn{4}{|c|}{ Rata-rata } \\
\hline
\end{tabular}

Sumber: Hasil Tabulasi Kuisioner 
Tabel 6. Pengembangan Karir

\begin{tabular}{|c|c|c|c|c|}
\hline Indikator & Nilai Minimum & $\begin{array}{c}\text { Nilai } \\
\text { Maksimum }\end{array}$ & $\begin{array}{c}\text { Nilai } \\
\text { Rata-rata }\end{array}$ & Standar Deviasi \\
\hline $\mathrm{PK}_{1}$ & 1 & 6 & 4.639 & 1.080 \\
\hline $\mathrm{PK}_{2}$ & 1 & 6 & 4.561 & 1.020 \\
\hline $\mathrm{PK}_{3}$ & 1 & 6 & 4.477 & 0.956 \\
\hline $\mathrm{PK}_{4}$ & 1 & 6 & 4.639 & 0.953 \\
\hline $\mathrm{PK}_{5}$ & 1 & 6 & 4.432 & 0.897 \\
\hline $\mathrm{PK}_{6}$ & 1 & 6 & 4.639 & 1.012 \\
\hline $\mathrm{PK}_{7}$ & 1 & 6 & 4.781 & 0.942 \\
\hline \multicolumn{3}{|c|}{ Rata-rata } & 4.595 & \\
\hline
\end{tabular}

Sumber: Hasil Tabulasi Kuisioner

Tabel 7. Kepuasan Kerja

\begin{tabular}{|c|c|c|c|c|}
\hline Indikator & Nilai Minimum & $\begin{array}{c}\text { Nilai } \\
\text { Maksimum }\end{array}$ & $\begin{array}{c}\text { Nilai } \\
\text { Rata-rata }\end{array}$ & Standar Deviasi \\
\hline $\mathrm{KK}_{1}$ & 1 & 6 & 4.626 & 1.254 \\
\hline $\mathrm{KK}_{2}$ & 1 & 6 & 4.755 & 1.107 \\
\hline $\mathrm{KK}_{3}$ & 1 & 6 & 4.755 & 1.192 \\
\hline $\mathrm{KK}_{4}$ & 1 & 6 & 4.748 & 1.171 \\
\hline $\mathrm{KK}_{5}$ & 1 & 6 & 4.748 & 1.091 \\
\hline $\mathrm{KK}_{6}$ & 1 & 6 & 4.748 & 1.097 \\
\hline $\mathrm{KK}_{7}$ & 1 & 6 & 4.690 & 1.096 \\
\hline \multicolumn{3}{|c|}{ Rata-rata } & 4.724 & \\
\hline
\end{tabular}

Sumber: Hasil Tabulasi Kuisioner

Tabel 8. Komitmen Organisasi

\begin{tabular}{|c|c|c|c|c|}
\hline Indikator & Nilai Minimum & $\begin{array}{c}\text { Nilai } \\
\text { Maksimum }\end{array}$ & $\begin{array}{c}\text { Nilai } \\
\text { Rata-rata }\end{array}$ & Standar Deviasi \\
\hline $\mathrm{KO}_{1}$ & 1 & 6 & 4.665 & 1.147 \\
\hline $\mathrm{KO}_{2}$ & 1 & 6 & 4.665 & 1.034 \\
\hline $\mathrm{KO}_{3}$ & 1 & 6 & 4.735 & 1.111 \\
\hline $\mathrm{KO}_{4}$ & 1 & 6 & 4.426 & 1.216 \\
\hline $\mathrm{KO}_{5}$ & 1 & 6 & 4.387 & 1.136 \\
\hline $\mathrm{KO}_{6}$ & 1 & 6 & 4.555 & 1.123 \\
\hline $\mathrm{KO}_{7}$ & 1 & 6 & 4.748 & 1.114 \\
\hline $\mathrm{KO}_{8}$ & 1 & 6 & 4.697 & 1.071 \\
\hline $\mathrm{KO}_{9}$ & 1 & 6 & 4.858 & 1.078 \\
\hline \multicolumn{3}{|c|}{ Rata-rata } & 4.637 & \\
\hline
\end{tabular}

Sumber: Hasil Tabulasi Kuisioner

Berdasarkan hasil pre-uji didapatkan nilai kesahihan dan kehandalan dari tiap indikator. Kepuasan gaji memiliki 4 (empat) indikator dengan nilai standar muatan faktor $>0,50$, nilai construct reliability 0.90054 dan nilai variance extracted 0.69672 . Sehingga nilai kesahihan dan kehandalan indikator kepuasan gaji baik. Pengembangan karir memiliki 7 (tujuh) indikator dengan nilai standar muatan faktor $>0,50$, nilai construct reliability 0.92271 dan nilai variance extracted 0.63256 . Sehingga nilai kesahihan dan kehandalan indikator pengembangan karir dikatakan baik. Kepuasan kerja memiliki 7 (tujuh) indikator dengan nilai standar muatan faktor $>0,50$, nilai construct reliability 0.93480 dan nilai variance extracted 0.67256. Sehingga nilai kesahihan dan kehandalan indikator kepuasan kerja dikatakan baik. Komitmen pada organisasi memiliki 9 (Sembilan) indikator dengan nilai standar muatan faktor $>0,50$, nilai construct reliability 0.93102 dan nilai variance extracted 0.60090 . Sehingga nilai kesahihan dan kehandalan indikator komitmen pada organisasi dikatakan baik. 
Berdasarkan hasil dari program Lisrel, pengolahan data terhadap 155 responden memperlihatkan hasil solusi terstandarisasi (standardized solution dan $t$ value) yang menunjukkan koefisien factor loading dan t-value antara masing-masing indikator pengukur terhadap peubah latennya memperlihatkan kelayakan model
(Goodness of Fit) yang baik. Nilai factor loading dari masing-masing indikator pengukur, nilainya di atas 0,50 (Igbaria et al., 1997). Sehingga disimpulkan bahwa penelitian ini tidak perlu dilakukan respesifikasi. Tabel berikut menunjukkan ringkasan penjelasan hasil uji kecocokan dari model struktural.

Tabel 9. Uji Kecocokan Model Struktural $(n=155)$

\begin{tabular}{|c|c|c|c|c|}
\hline No & Indikator & Indikator Standar & Hasil Pengujian & Keterangan \\
\hline 1 & $\begin{array}{l}\text { Adjusted Goodness of } \\
\text { Fit Index (AGFI) }\end{array}$ & $\geq 0.90$ & 0.80 & $\begin{array}{l}\text { Kecocokan } \\
\text { Marjinal }\end{array}$ \\
\hline 2 & $\begin{array}{l}\text { Akaike Information } \\
\text { Index (AIC) }\end{array}$ & $\begin{array}{l}<\text { AIC Saturated dan } \\
\text { Independence Model }\end{array}$ & $\begin{array}{l}\text { Independence AIC = } 12511.99 \\
\text { Model AIC }=550.16 \\
\text { Saturated AIC }=756.00 \\
\text { Model AIC lebih dekat ke Saturated } \\
\text { AIC daripada ke Independence AIC }\end{array}$ & Kecocokan Baik \\
\hline 3 & Chi Square & Diharapkan kecil & 432.11 & $\begin{array}{c}\text { Kecocokan } \\
\text { Kurang Baik }\end{array}$ \\
\hline 4 & $\begin{array}{l}\text { Comparative Fit Index } \\
(\mathrm{CFI})\end{array}$ & $>0.90 ;>0.95$ & 0.99 & Kecocokan Baik \\
\hline 5 & $\begin{array}{l}\text { Consistent Akaike } \\
\text { Information Index } \\
\text { (CAIC) }\end{array}$ & $\begin{array}{l}<\text { CAIC Saturated dan } \\
\text { Indepence Model }\end{array}$ & $\begin{array}{l}\text { Independence CAIC }=12621.17 \\
\text { Model CAIC }=792.76 \\
\text { Saturated CAIC }=2284.41 \\
\text { Model CAIC lebih dekat ke } \\
\text { Saturated CAIC daripada ke } \\
\text { Independence CAIC }\end{array}$ & Kecocokan Baik \\
\hline 6 & Degree of Freedom & Diharapkan besar & 318 & Kecocokan Baik \\
\hline 7 & $\begin{array}{l}\text { Expected Cross } \\
\text { Validation Index } \\
\text { (ECVI) }\end{array}$ & $\begin{array}{l}<\text { ECVI Saturated dan } \\
\text { Independence Model }\end{array}$ & $\begin{array}{l}\text { Expected Cross-Validation Index } \\
(\text { ECVI) }=3.57 \\
\text { ECVI for Saturated Model }=4.91 \\
\text { ECVI for Independence Model }= \\
81.25 \\
\text { Model ECVI lebih dekat ke Saturated } \\
\text { ECVI daripada ke Independence } \\
\text { ECVI }\end{array}$ & Kecocokan Baik \\
\hline 8 & Goodness of Fit (GFI) & $>0.90$ & 0.83 & $\begin{array}{c}\text { Kecocokan } \\
\text { Marginal }\end{array}$ \\
\hline 9 & $\begin{array}{l}\text { Incremental Fit Index } \\
\text { (IFI) }\end{array}$ & $>0.90 ;>0.95$ & 0.99 & \\
\hline 10 & $\begin{array}{l}\text { Non Centraly } \\
\text { Parameter }(\mathrm{NCP})\end{array}$ & $\begin{array}{l}\text { Independence } \\
\text { Model }\end{array}$ & $\begin{array}{l}\text { Estimated Non-centrality Parameter } \\
(\mathrm{NCP})=112.16 \\
\text { Model } 90 \text { Percent Confidence } \\
\text { Interval for NCP }=(61.99 ; 170.40)\end{array}$ & Kecocokan Baik \\
\hline 11 & Normed Fit Index (NFI) & $>0.90 ;>0.95$ & 0.97 & Kecocokan Baik \\
\hline 12 & $\begin{array}{l}\text { Parsimonious Normed } \\
\text { Fit Index (PNFI) }\end{array}$ & $0.60-0.90$ & 0.87 & Kecocokan Baik \\
\hline 13 & $\begin{array}{l}\text { Parsimonious Goodness } \\
\text { of Fit Index (PGFI) }\end{array}$ & $>0.60$ & 0.70 & Kecocokan Baik \\
\hline 14 & Probability & $\geq 0.50$ & 0.88 & Kecocokan Baik \\
\hline 15 & P Value for RMSEA & $>0.050$ & 0.61 & Kecocokan Baik \\
\hline 16 & Relative Fit Index (RFI) & $>0.90 ;>0.95$ & 0.96 & Kecocokan Baik \\
\hline 17 & $\begin{array}{l}\text { Root Mean Square } \\
\text { Error Approximation } \\
\text { (RMSEA) }\end{array}$ & $0.05-0.08$ & 0.048 & $\begin{array}{c}\text { Kecocokan } \\
\text { Marginal }\end{array}$ \\
\hline 18 & $\begin{array}{l}\text { Root Mean Square } \\
\text { Error Residual } \\
\text { (RMSER) }\end{array}$ & $<0.08$ & 0.053 & Kecocokan Baik \\
\hline
\end{tabular}

Sumber: Pengolahan Data 
Hasil uji hipotesis dengan program Lisrel terdapat pada path diagram. Pengaruh yang positif ditunjukkan dengan nilai $t$-value lebih besar daripada t-tabel. Hubungan yang positif ditandai dengan t-value dengan nilai $\geq 1,96$, sedangkan hubungan yang negatif ditandai dengan t-value dengan nilai $<1,96$. Gambar berikut adalah output dari path diagram yang menunjukkan hasil solusi terstandarisasi (standardized solution) koefisien jalur antar peubah dan nilai tvalue.

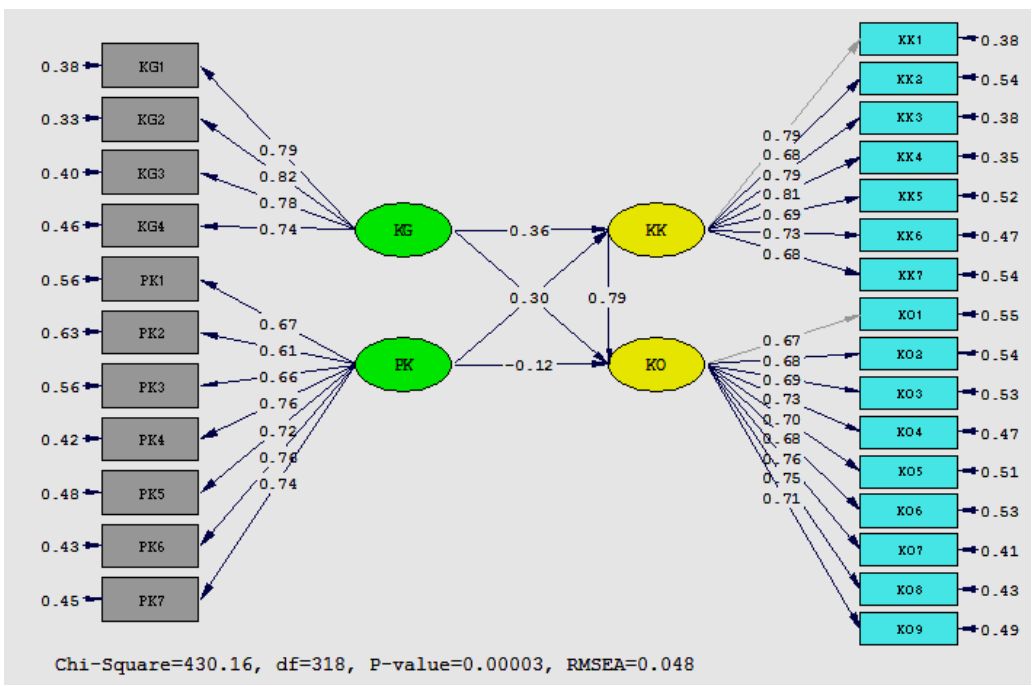

Sumber: Pengolahan Data

Gambar 2 Model Struktural - standardized solution

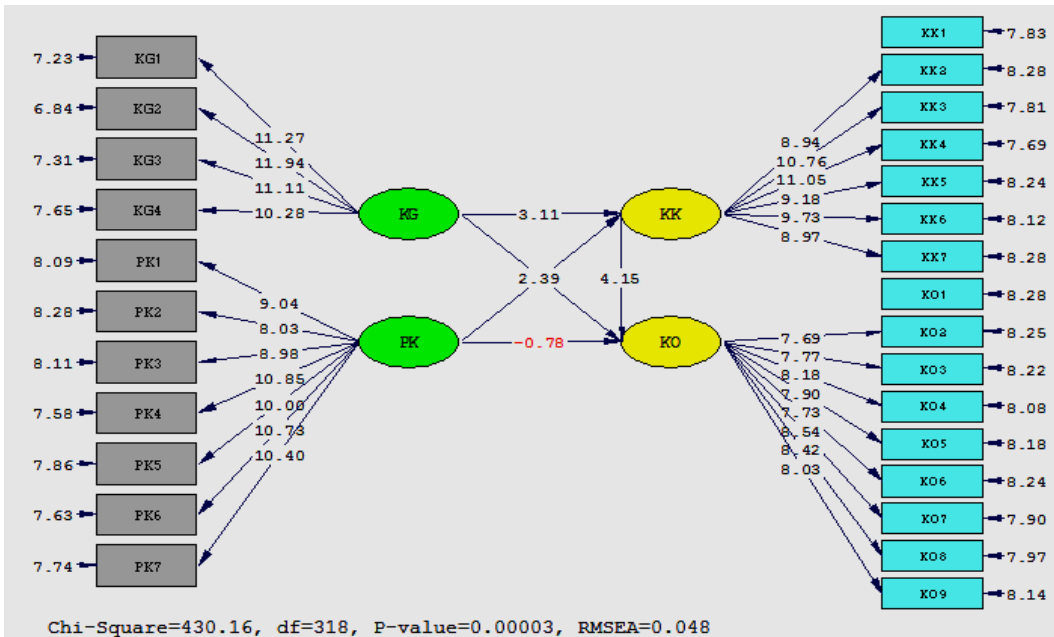

Sumber: Pengolahan Data

Gambar 3. Model Struktural - $t$ Value

Nilai t-value kepuasan gaji terhadap komitmen pada organisasi adalah 2.39. Nilai $\mathrm{t}$-value kepuasan gaji terhadap kepuasan kerja adalah 3.11. Nilai t-value pengembangan karir terhadap komitmen pada organisasi adalah -0.78 . Nilai t-value pengembangan karir terhadap kepuasan kerja adalah 4.91. Nilai t-value kepuasan kerja terhadap komitmen pada organisasi adalah 4.15. Tabel dibawah ini menunjukkan ringkasan hasil pengujian hipotesis. 
Tabel 10. Hasil Pengujian Hipotesis $(n=155)$

\begin{tabular}{|c|l|c|c|c|c|}
\hline Hipotesis & \multicolumn{1}{|c|}{ Alur $($ Path $)$} & Estimate & $\begin{array}{c}\text { Nilai t } \geq \\
\mathbf{1 , 9 6}\end{array}$ & $\begin{array}{c}\text { Signifikansi } \\
\boldsymbol{a = 0 , 1 0}\end{array}$ & Kesimpulan \\
\hline 1 & $\begin{array}{l}\text { Kepuasan Gaji } \longrightarrow \text { Komitmen } \\
\text { pada Organisasi }\end{array}$ & 0.30 & 2.39 & Signifikan & $\begin{array}{c}\text { Hipotesis } \\
\text { didukung }\end{array}$ \\
\hline 2 & $\begin{array}{l}\text { Kepuasan Gaji } \longrightarrow \text { Kepuasan } \\
\text { Kerja }\end{array}$ & 0.36 & 3.11 & Signifikan & $\begin{array}{c}\text { Hipotesis } \\
\text { didukung }\end{array}$ \\
\hline 3 & $\begin{array}{l}\text { Pengembangan Karir - } \\
\text { Komitmen pada Organisasi }\end{array}$ & -0.12 & -0.78 & $\begin{array}{c}\text { Tidak } \\
\text { Signifikan }\end{array}$ & $\begin{array}{c}\text { Hipotesis } \\
\text { tidak } \\
\text { didukung }\end{array}$ \\
\hline 5 & $\begin{array}{l}\text { Pengembangan Karir } \longrightarrow \\
\text { Kepuasan Kerja }\end{array}$ & 0.60 & 4.91 & Signifikan & $\begin{array}{l}\text { Hipotesis } \\
\text { didukung }\end{array}$ \\
\hline 5 & $\begin{array}{l}\text { Kepuasan Kerja } \longrightarrow \\
\text { Komitmen pada Organisasi }\end{array}$ & 0.79 & 4.15 & Signifikan & $\begin{array}{l}\text { Hipotesis } \\
\text { didukung }\end{array}$ \\
\hline
\end{tabular}

Sumber: Hasil Pengolahan Data

Koefisien determinasi $\left(\mathrm{R}^{2}\right)$ digunakan untuk mengetahui persentase sumbangan pengaruh peubah bebas terhadap peubah terikat. Menurut Joreskog dalam Latan (2013), koefisien determinasi $\left(\mathrm{R}^{2}\right)$ pada structural equation hasil olahan Lisrel diambil dari reduced from equation. Koefisien determinasi $\left(\mathrm{R}^{2}\right)$ antara peubah kepuasan gaji dan pengembangan karir terhadap kepuasan kerja adalah 0.84 atau sebesar $84 \%$. Koefisien Determinasi $\left(\mathrm{R}^{2}\right)$ antara peubah kepuasan gaji dan pengembangan karir terhadap komitmen pada organisasi adalah 0.80 atau sebesar $80 \%$. Koefisien determinasi $\left(\mathrm{R}^{2}\right)$ antara peubah laten kepuasan gaji, pengembangan karir dan kepuasan kerja terhadap komitmen pada organisasi adalah 0.90 atau sebesar $90 \%$.

Analisis pengaruh diperlukan untuk mengetahui besar pengaruh peubah bebas terhadap peubah terikat, baik secara langsung maupun tidak langsung. Tanda koefisien menunjukkan hubungan langsung (positif atau negatif) antara peubah laten dalam penelitian. Koefisien jalur (beta) menunjukkan pengaruh secara langsung maupun tidak langsung pada setiap peubah laten. Total pengaruh merupakan jumlah dari seluruh pengaruh langsung dan pengaruh tidak langsung. Tabel berikut merupakan ringkasan hasil pengujian pengaruh langsung, pengaruh tidak langsung dan pengaruh total.

Tabel 11. Pengaruh Langsung, Pengaruh Tidak Langsung dan Pengaruh Total antar Peubah Laten $(\mathbf{n}=\mathbf{1 5 5})$

\begin{tabular}{|c|c|c|c|c|c|c|}
\hline No. & Alur (Path) dari & Ke & $\begin{array}{c}\text { Peubah } \\
\text { pemediasi }\end{array}$ & $\begin{array}{c}\text { Pengaruh } \\
\text { Langsung }\end{array}$ & $\begin{array}{c}\text { Pengaruh } \\
\text { Tidak } \\
\text { Langsung }\end{array}$ & $\begin{array}{c}\text { Pengaruh } \\
\text { Total }\end{array}$ \\
\hline 1 & Kepuasan Gaji & $\begin{array}{c}\text { Komitmen } \\
\text { Pada } \\
\text { Organisasi }\end{array}$ & $\begin{array}{c}\text { Kepuasan } \\
\text { Kerja }\end{array}$ & 0.30 & 0.2844 & 0.5844 \\
\hline 2 & Kepuasan Gaji & $\begin{array}{c}\text { Kepuasan } \\
\text { Kerja }\end{array}$ & - & 0.36 & - & 0.36 \\
\hline 3 & $\begin{array}{c}\text { Pengembangan } \\
\text { Karir }\end{array}$ & $\begin{array}{c}\text { Komitmen } \\
\text { pada } \\
\text { Organisasi }\end{array}$ & $\begin{array}{c}\text { Kepuasan } \\
\text { Kerja }\end{array}$ & -0.12 & 0.474 & 0.354 \\
\hline 5 & $\begin{array}{c}\text { Kengembangan } \\
\text { Karir }\end{array}$ & $\begin{array}{c}\text { Kepuasan } \\
\text { Kerja }\end{array}$ & - & 0.60 & - & 0.25 \\
\hline
\end{tabular}

Sumber: Hasil Pengolahan Data 
Nilai koefisien jalur kepuasan gaji terhadap komitmen pada organisasi sebesar 0.30. Nilai koefisien jalur kepuasan gaji terhadap kepuasan kerja sebesar 0.36. Nilai koefisien jalur pengembangan karir terhadap komitmen pada organisasi sebesar -0.12. Nilai koefisien jalur pengembangan karir terhadap kepuasan kerja sebesar 0.60. Nilai koefisien jalur kepuasan kerja terhadap komitmen pada organisasi sebesar 0.79.

Kepuasan gaji mempunyai pengaruh langsung terhadap komitmen organisasi dengan nilai koefisien jalur sebesar 0.30 dan memiliki pengaruh tidak langsung melalui kepuasan kerja sebesar 0.2844. Total pengaruh hubungan sebesar 0.5844 atau $58,44 \%$. Hal ini berarti kepuasan gaji berkontribusi terhadap komitmen pada organisasi sebesar 58,44\% melalui kepuasan kerja.

Pengembangan karir mempunyai pengaruh langsung terhadap komitmen organisasi dengan nilai koefisien jalur sebesar -0.12 dan memiliki pengaruh tidak langsung melalui kepuasan kerja sebesar 0.474 . Total pengaruh hubungan sebesar 0.354 atau $35,4 \%$. Hal ini berarti pengembangan karir berkontribusi terhadap komitmen pada organisasi sebesar $35,40 \%$ melalui kepuasan kerja.

Hasil analisis jalur terhadap model struktural hipotesis secara keseluruhan menunjukkan kecocokan pengukuran model struktural yang tepat dari 155 responden. Model akhir hasil penelitian dapat dilihat pada gambar berikut:

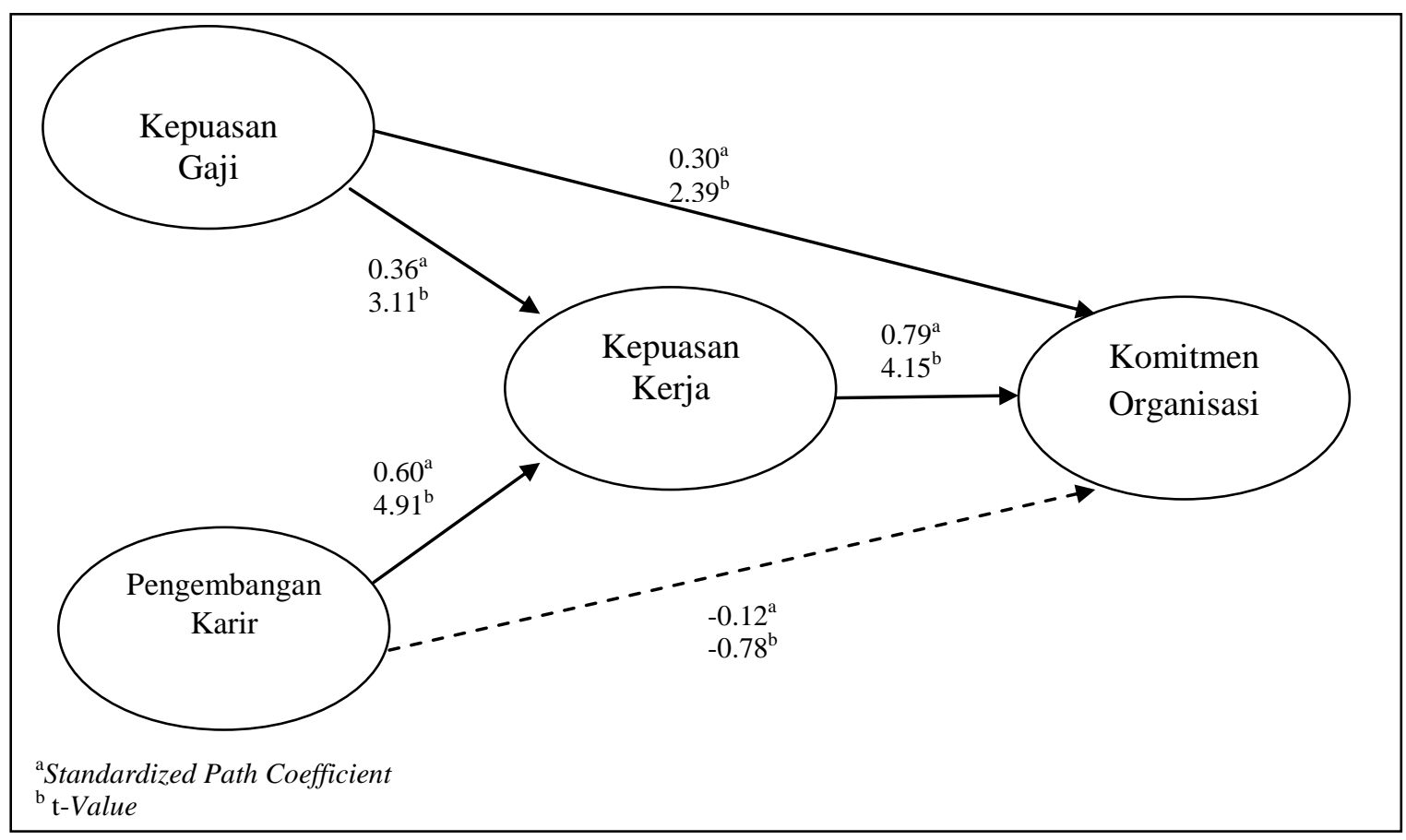

Sumber: Hasil Pengolahan Data

Gambar 4. Model Akhir Hasil Penelitian $(\mathrm{n}=155)$ 


\section{PEMBAHASAN HASIL PENELITIAN}

Hipotesis pertama menyatakan kepuasan gaji memengaruhi secara positif terhadap komitmen pada organisasi. Hasil penelitian menunjukkan kepuasan gaji memengaruhi secara positif terhadap komitmen pada organisasi guru Sekolah Menengah Pertama (SMP) swasta di kota Tangerang. Hal ini dibuktikan dengan nilai t-value sebesar 2.39. Koefisisen jalur kepuasan gaji terhadap komitmen pada organisasi sebesar 0.30, hal ini berarti kepuasan gaji berkontribusi terhadap komitmen pada organisasi sebesar 30\%, sedangkan sisanya $70 \%$ dipengaruhi oleh faktor-faktor lain. Penelitian ini mendukung teori dari Abdullah \& Ramay (2012); Azeem (2010); Currall et al., (2005); Miceli dan Mulvey, (2000); dan Vanderberghe dan Trembley (2008) yang menyatakan kepuasan gaji memengaruhi secara positif dan signifikan terhadap komitmen pada organisasi.

Sebagaimana menurut Lum et al., (1998) bahwa individu akan merasakan keadilan (equity) terhadap gaji yang diterima sehubungan dengan pekerjaan yang dilakukannya. Sinclair et al., (2005) menunjukkan kekuatan dari uang dengan proses pilihan pekerjaan bahwa uang memiliki kekuatan untuk menarik, mempertahankan, dan memotivasi individu terhadap kinerja yang lebih tinggi. Jika seorang karyawan memiliki tawaran pekerjaan lain, yang menawarkan imbalan keuangan yang lebih besar dan memiliki karakteristik pekerjaan yang identik dengan pekerjaannya yang sekarang, pekerja kemungkinan besar akan termotivasi untuk menerima tawaran pekerjaan baru tersebut. Hal ini menunjukkan kekuatan kepuasan gaji sangat memengaruhi komitmen guru pada organisasinya.

Hipotesis kedua menyatakan kepuasan gaji memengaruhi secara positif terhadap kepuasan kerja. Hasil penelitian menunjukkan kepuasan gaji memengaruhi secara positif terhadap kepuasan kerja guru Sekolah Menengah Pertama (SMP) swasta di kota Tangerang. Hal ini dibuktikan dengan nilai t-value sebesar 3.11. Koefisisen jalur kepuasan gaji terhadap kepuasan kerja sebesar 0.36, hal ini berarti kepuasan gaji berkontribusi terhadap kepuasan kerja sebesar 36\%, sedangkan sisanya $64 \%$ dipengaruhi oleh faktor-faktor lain. Penelitian ini mendukung hasil penelitian Lum et al., (1998); Judge et al., (2010); Bartol dan Liu (2005); Odunlade (2012); Nisaret al., (2012); Al-Zoubi (2012) yang menyatakan kepuasan gaji memengaruhi secara positif dan signifikan terhadap kepuasan kerja.

Brown et al., (2007) menjelaskan bahwa kepuasan kerja berbanding lurus dengan jumlah gaji yang diterima oleh karyawan. Gaji ditemukan menjadi faktor utama meningkatkan kepuasan kerja karyawan merupakan hasil penelitian yang dilakukan oleh Bartol dan Liu (2005). Sehingga meningkatkan kepuasan gaji guru adalah salah satu cara organisasi untuk menaikkan kepuasan kerja guru dan meningkatkan kualitas layanan dan kinerja di sekolah.

Hipotesis ketiga menyatakan pengembangan karir memengaruhi secara positif terhadap komitmen pada organisasi. Hasil penelitian menunjukkan pengembangan karir tidak memengaruhi komitmen pada organisasi guru Sekolah Menengah Pertama (SMP) swasta di kota Tangerang. Hal ini dibuktikan dengan nilai $\mathrm{t}$-value sebesar -0.78. Koefisisen jalur pengembangan karir terhadap komitmen pada organisasi sebesar -0.12 . Penelitian ini tidak mendukung hasil penelitian dari Ogaboh et al., (2010); Riveros \& Tsai (2011); Adio \& Popoola (2009); Chang (1999); Goulet dan Singh (2002); Weng et al., (2010); Bashir \& ramay (2008); yang menyatakan bahwa pengembangan karir memengaruhi secara positif dan signifikan terhadap komitmen pada organisasi.

Hal ini mengindikasikan proses promosi guru menjadi Kepala Sekolah oleh Yayasan tempat mereka bekerja kurang terbuka dan kemungkinan berdasarkan rasa suka atau tidak suka, selain itu pihak yayasan harusnya senantiasa menjalin komunikasi dengan guru tentang kebutuhan karir guru. Oleh karena itu jika organisasi ingin memiliki karyawan yang puas dengan pekerjaannya dan tidak akan pernah ingin meninggalkan organisasi, maka organisasi 
harus berinvestasi dalam program pengembangan karir yang jelas (Patrick, 2011).

Hasil penelitian dari Adler dan Araya, Angle dan Perry, Brief dan Alday (Chairy, 2002), menunjukkan komitmen terhadap organisasi terbukti berkolerasi dengan umur dan masa kerja. Berdasarkan faktor usia dari responden menunjukkan bahwa mayoritas responden dalam penelitian ini terletak pada kelompok usia muda. Guru yang berusia muda akan cenderung berpindah-pindah mencari sekolah lain dibandingkan guru yang berusia tua.

Penelitian Cherrington menemukan bahwa kaitan hubungan antara usia dan komitmen disebabkan karena semakin tua karyawan, semakin berkomitmen pada organisasi, selain itu serta karyawanyang lebih tua memiliki atau merasa memiliki pengalaman positif tentang organisasi,sehingga meningkatkankesetiaan mereka pada organisasi.

Hipotesis keempat menyatakan pengembangan karir memengaruhi secara positif terhadap kepuasan kerja. Hasil penelitian menunjukkan pengembangan karir memengaruhi secara positif terhadap kepuasan kerja guru Sekolah Menengah Pertama (SMP) swasta di kota Tangerang. Hal ini dibuktikan dengan nilai t-value 4.90. Koefisisen jalur pengembangan karir terhadap kepuasan kerja 0.60 , hal ini berarti pengembangan karir berkontribusi $60 \%$ terhadap kepuasan kerja sedangkan sisanya $40 \%$ dipengaruhi oleh faktor-faktor lain. Penelitian ini mendukung hasil penelitian dari Chen et al., (2004); Adekola, (2011); Kalayar et al., (2009); Shujaat et al., (2013); Chen \& Tsai (2012); yang menyatakan pengembangan karir memengaruhi secara positif dan signifikan terhadap kepuasan kerja.

Program pengembangan karir dalam upaya pengembangan potensi guru berupa pelatihan guru, sekolah lanjutan, Forum Kelompok Kerja Guru (FKKG), Musyawarah Guru Mata Pelajaran (MGMP), Kelompok Kerja Guru (KKG), seminar, diskusi dsb. Hal ini bertujuan agar guru dapat mengikuti perkembangan ilmu pengetahuan dan teknologi serta memberikan kesempatan kepada yang bersangkutan meningkatkan kompetensinya sebagai guru di jenjang karir secara fungsional. Kegiatan pengembangan karir yang dilakukan sekolah swasta berpengaruh terhadap kepuasan kerjanya. Kegiatan pengembangan karir sangat terkait dengan kepuasan guru untuk mencapai tujuan dari organisasi. Dari hasil analisis dapat dijelaskan guru yang memperoleh kejelasan pengembangan karir akan memiliki kepuasan kerja yang tinggi.

Hipotesis kelima menyatakan kepuasan kerja memengaruhi secara positif terhadap komitmen pada organisasi. Hasil penelitian menunjukkan kepuasan kerja memengaruhi secara positif terhadap komitmen pada organisasi. Hal ini dibuktikan dengan nilai t-value 4.15. Koefisisen jalur kepuasan kerja terhadap komitmen pada organisasi 0.79, hal ini berarti kepuasan kerja berkontribusi $79 \%$ terhadap komitmen pada organisasi, sedangkan sisanya $21 \%$ dipengaruhi oleh faktor-faktor lain. Penelitian ini mendukung hasil penelitian dari Okpara (2004); ChiunLo dan Ramayah (2011); Naderi (2012); Abdullah dan Ramay (2012); Mathur \& Salunke (2013); Mohamadkhani et al., (2012); Nguyen et al., (2014) yang menyatakan kepuasan kerja memengaruhi secara positif dan signifikan terhadap komitmen pada organisasi.

Guru yang senang dengan pekerjaannya serta mendapatkan kesempatan untuk belajar hal-hal yang baru akan meningkatkan kesetiaan pada organisasi tempatnya bekerja. Guru yang puas dengan gaji yang diterima serta tunjangan yang sesuai dengan tanggung jawab pekerjaan mengindikasikan refleksi dari bagaimana manajemen memandang kontribusi mereka terhadap sekolah. Hal ini secara tidak langsung akan menimbulkan suatu perasaan untuk tetap komitmen dan bertahan dalam sekolah. Ketika kebutuhan mereka terpenuhi maka tingkat komitmen organisasi mereka akan menjadi tinggi. 


\section{SIMPULAN dan SARAN}

\section{Simpulan}

1. Komitmen pada organisasi dipengaruhi secara positif oleh kepuasan gaji. Hal ini dibuktikan dengan nilai t-value sebesar 2.39. Nilai koefisien jalur kepuasan gaji terhadap komitmen pada organisasi sebesar 0.30. Ini berarti kepuasan gaji berkontribusi terhadap komitmen organisasi sebesar 30\%, sedangkan sisanya $70 \%$ dipengaruhi oleh faktor-faktor lain. Hal ini menandakan guru yang merasa puas terhadap tingkat gaji, struktur pengelolaan gaji, kenaikan gaji dan tunjangan yang diberikan oleh sekolah yang sesuai dengan keinginan guru sehingga menunjukkan komitmen pada organisasinya.

2. Kepuasan kerja dipengaruhi secara positif oleh kepuasan gaji. Hal ini dibuktikan dengan nilai t-value sebesar 3.11. Nilai koefisien jalur kepuasan gaji terhadap kepuasan kerja sebesar 0.36. Ini berarti kepuasan gaji berkontribusi terhadap kepuasan kerja sebesar 36\%, sedangkan sisanya $64 \%$ dipengaruhi oleh faktor-faktor lain. Gaji yang diberikan kepada guru mempertimbangkan prinsip keadilan dan kelayakan bagi guru serta gaji yang diberikan sesuai dengan kemampuan, keahlian dan harapan yang guru miliki.

3. Komitmen pada organisasi tidak dipengaruhi pengembangan karir. Hal ini dibuktikan dengan nilai tvalue sebesar -0.78. Nilai koefisien jalur pengembangan karir terhadap komitmen padaorganisasi sebesar 0.12 . Ini berarti pengembangan karir tidak berkontribusi terhadap komitmen pada organisasi. Hal ini kemungkinan disebabkan jenjang karir struktural guru swasta adalah Kepala Sekolah. Untuk menduduki suatu jabatan tertentu secara struktural ada syarat-syarat yang harus dipenuhi sesuai dengan ketentuan dari Yayasan tempat guru bekerja. Hal ini terlihat jawaban responden pada kuisioner menunjukkan rata-rata terendah adalah proses pengembangan karir secara terbuka yang mengindikasikan proses promosi guru menjadi Kepala Sekolah oleh Yayasan tempat mereka bekerja kurang terbuka.

4. Kepuasan kerja dipengaruhi secara positif oleh pengembangan karir. Hal ini dibuktikan dengan nilai t-value 4.90. Nilai koefisien jalur pengembangan karir terhadap kepuasan kerja 0.60. Ini berarti pengembangan karir berkontribusi $60 \%$ terhadap kepuasan kerja, sedangkan sisanya $40 \%$ dipengaruhi oleh faktor-faktor lain. Hal ini mengindikasikan apa yang menjadi program karir guru telah sesuai dengan apa yang dirasakan guru dalam sekolah. Guru yang senang dengan pola pengembangan karir sekolah dan mendapatkan kesempatan untuk belajar hal-hal yang baru dalam rangka meningkatkan profesionalitasnya sebagai guru sehingga memengaruhi kepuasan kerjanya.

5. Komitmen pada organisasi dipengaruhi secara positif oleh kepuasan kerja. Hal ini dibuktikan dengan nilai dengan t-value 4.15. Nilai koefisien jalur kepuasan kerja terhadap komitmen pada organisasi 0.79. Ini berarti kepuasan kerja berkontribusi $79 \%$ terhadap komitmen pada organisasi, sedangkan sisanya $21 \%$ dipengaruhi oleh faktor-faktor lain. Hal ini mengindikasikan apa yang menjadi harapan sesuai dengan apa yang 
dirasakan guru dalam sekolah. Hal ini secara langsung akan menimbulkan suatu perasaan untuk tetap komitmen dan bertahan dalam sekolah.

\section{Keterbatasan Penelitian}

Dalam penelitian ini terdapat beberapa keterbatasan yang dapat memengaruhi kondisi dari penelitian yang dilakukan. Adapun keterbatasan tersebut adalah:

1. Penelitian ini dibuat untuk meneliti tentang komitmen pada organisasi dengan faktor yang memengaruhinya, yakni, kepuasan gaji, pengembangan karir dan kepuasan kerja pada guru Sekolah Menengah Pertama (SMP) swasta di kota Tangerang. Kemungkinan terdapat peubah lain yang memengaruhi komitmen pada organisasi.

2. Keterbatasan lain dalam penelitian ini adalah objek penelitian adalah guru Sekolah Menengah Pertama (SMP) swasta di Kota Tangerang. Kemungkinan ada perbedaan hasil dan kesimpulan bila dilakukan untuk objek dengan profesi berbeda.

3. Keterbatasan selanjutnya bahwa metode yang digunakan dalam penelitian ini adalah survei hanya melalui kuesioner. Penelitian ini tidak menggunakan wawancara secara langsung kepada guru yang bersangkutan, sehingga simpulan yang diambil hanya berdasarkan pada data yang dikumpulkan melalui penggunaan instrumen secara tertulis.

\section{DAFTAR PUSTAKA}

Abdullah, Muhammad., Ramay, Ismail. 2012. Antecedents $O F$ Organizational Commitment Of Banking Sector Employees In Pakistan. Serbian Journal of Management 7 (1) (2012) 89 - 102. Department of Management Sciences, International Islamic University Islamabad, H-10, Islamabad, Pakistan.
Adekola, Bola. 2011. Career Planning and Career Management as Correlates For Career Development and Job Satisfaction: A Case Study of Nigerian Bank Employees. Australian Journal of Business and management Research, Vol.1 No.2, h. $100-112$.

Adio, Gboyega and S.O. Popoola. 2009. Job Satisfaction and Career Commitment of Librarians in Federal University Libraries in Nigeria. Career Development International Journal. Vol. 59 No. 3, h. $175-184$.

Al-Zoubi, Marwan. 2012. The sape of relationship between salary and job satisfaction: a field study. Far East Journal Psychology and Business. Vol.7 No. 3 June 2012.

Azeem, Syed, M. 2010. Job Satisfaction and Organizational Commitment among Employees in the Sultanate of Oman. Psychology. Vol 1, 295-299.

Bartol, Tekleab, A.G., K.M. and W. Liu. 2005. "Is it Pay Levels or Pay Raise that Matter to Fairness and Turnover?" Journal of Organizational Behaviour, 26, 899921.

Bashir, Sajid \& Ramay, Mohammad Ismail. 2008. Determinants of Organizational Commitment A Study of Information Technology Professionals in Pakistan. Copyright (C) 2008 Institute of Behavioral and Applied Management.

Brown, U.J., and Gaylor, K.P. 2007. Organizational commitment in higher education. Unpublished Manuscript, Jackson State University, Jackson, MS.

Chairy, Liche Seniati. 2002. Seputar Komitmen Organisasi. Universitas Indonesia, Jakarta 
Chang, Eunmi. 1999. Career commitment as a complex moderator of organizational commitment and turnover intention. Human Relations, 52(10), 1257-1278.

Cherrington, David J. 1994. Organizational Behavior: The Management of Individual and Organizational Performance, Second Edition, Allyn \& Bacon, Boston.

Chungtai, AAmin Ali dan Rohail Zafar. 2006. "Antecendents and consequensces or organitational Commitment Among Pakistan University Teacher" Appliend H.R.M research, 2006, 11 (1): 3964.

Chiun Lo, May dan Ramayah, T. 2011. Mentoring and job satisfaction in Malaysian SMEs, Journal of Management Development, Vol 30, Iss 4. pp427-440.

Currall, S.C., A.J. Towler, T.A. Judge and L. Kohn. 2005. "Pay Satisfaction and Organizational Outcomes." Personnel Psychology, 58 (3), 613$640 . \quad$ DOI: $10.1111 / \mathrm{j} .1744$ 6570.2005.00245.

Curry, J.P., Wakefield, D.S., Price, J.L. and Mueller, C.W. 1986. On the causal ordering of job satisfaction and organizational committment. Academy of Management Journal, 29: 847-858 .

Dessler, Gary. 2005. Manajemen Sumber Daya Manusia. Alih bahasa: Eli Tanya. Penyunting Bahasa: Budi Supriyanto. Jakarta.

De simone, R.L., Werner, J.M., \& Harris, D.M. 2001. Human Resource Management. 3Ed., Fort Worth, Harcourt College Published.

Goulet, L.R. \& Singh, P. 2002. "Career Commitment: A Re-examination and an Extension", Journal of Vocational Behaviour, Vol. 61, no. 1, pp. 73-91.
Hair, J. F., Black, W. C., Babin,B. J., \& Anderson, R. E. 2010. Multivariate Data Analysis. 7th Edition,Pearson Prentice Hall, New Jersey.

Hasibuan, Malayu SP. 2009. Manajemen Sumber Daya Manusia, Edisi Revisi, PT. Bumi Aksara, Jakarta.

Heneman, H.G., and D.P. Schwab. 1985. "Pay Satisfaction: Its Multidimensional Nature and Measurement." International Journal of Psychology, 20, 129-141.

Heery, E \& Noon, M. 2006. A Dictionary of human resource management.Oxford University Press, New York.

Jones, R. Sloane, P. 2007. Low pay, higher pay and Job satisfaction in wales. Spatial Economic Analysis. 2, (2)pp. 197-214.

Judge, T.A., Thoresen, C.J., Bono, J.E., \& Patton, G.K. 2001. The job satisfaction-job performance relationship: A qualitative and quantitative review. Psychological Bulletin, 127(3): 376-407.

Judge, Timothy A., Piccolo, Ronald F., Podsakoff, Nathan P. Shaw, John C., Rich Bruce L. 2010. The relationship between pay and job satisfaction: A meta-analysis of the literature. Journal of Vocational Behavior 77 157-167.journal homepage:

www.elsevier.com/locate/jvb

Kayalar, Murat \& ÖZMUTAF, Metin. 2009. The Effect Of Individual Career Planning On Job Satisfaction: A Comparative Study On Academic And Administrative Staff. Suleyman Demirel University The Journal of Faculty of Economics and Administrative Sciences Y.2009, Vol.14, No.1 pp.239-254. 
Kreitner, Robert \& Kinicki., Anggelo. 2005. Perilaku Organisasi. Salemba Empat, Jakarta.

Labbase, Ilham. 2010. Faktor-faktor yang berpengaruh terhadap pengembangan Karir pegawai dinas Perikanan dan kelautan Propinsi Sulawesi Selatan, Jurnal Economic Resources, ISSN. 0852-1158, Vol.11 No.31,Juni 2010. Hal. 127145 .

Latan, Hengky. 2013. Structural Equation Modelling Konsep dan Aplikasi menggunakan Program Lisrel 8.80. Alfabeta, Bandung.

Lum, Lille, John Kervin, Kathleen Clark, Frank Reid \& Wendy Sola, 1998, Explaining Nursing Turnover Intent: Job Satisfaction, Pay Satisfaction, or Organizational Commitment. Journal of Organizational Behavior. Vol. 19, 305-320.

Luthans, Fred. 2006. Perilaku Organisasi. Diterjemahkan oleh Vivin Andika Yuwono dkk. Edisi Pertama, Penerbit Andi, Yogyakarta.

Mathur, Garima. Megha Salunke. 2013. Organizational commitment and Job Satisfaction: A study of Manufacturing Sector, Volume.4. Issue.1.

Meyer \& Allen, Benkhoff, Birgit. 1997. Ignoring Commitment is Costly: New Approaches Establish The Missing Link Between and Performance, Human Relations, Vol.50, No.6, pp:701-726.

Miceli, Marcia P. \& Lane, Matthew C. 1991. Antecedents of pay satisfaction: A review and extension, Research in Personnel and Human Resources and Management, 9, 235-309.

Mohamadkhani, K \& M. Nasiri Lalardi. 2012. Emotional Intelligence and Organizational Commitment between the Hotel Staff in Tehran, Iran, American Journal of Business and Management Vol. 1, No. 2, 2012, 54-59.

Mobley, W. H., Griffeth, R. W., Hand, H. H. and Meglino, B.M. 2006. Review and Conceptual analysis of the employee turnover process, Journal of applied Psychology, 72, 221-227.

Mowday, R. T., R. M. Steers and I. W. Porter, 1979, "The Measurement of Organizational Commitment", Journal of Applied Psychology, 84, p.408-414.

Muthuveloo, Rajendran dan Raduan Che Rose. 2005. "Typology of Organizational Commitment." American Journal of Applied Science, 2 (6): 1078-1081.

Naderi Anari, Nahid. 2012. Teachers: emotional intelligence, job satisfaction, and organizational commitment, Vol 24, Iss 4. pp 256269.

Nguyen, Tung N., Mai, Khuong N., \& Nguyen, Phuong V. 2014. Factors Affecting Employees' Organizational Commitment-A Study of Banking Staff in Ho Chi Minh City, Vietnam. Journal of Advanced Management Science Vol. 2,No.1, March 2014. Vietnam National University, Ho Chi Minh City, Vietnam.

Nisar, Ali. Zafar, Muhammad Iqbal. Mahmood, Babak. Sohail, Malik Muhammad. Sher, Falak. Safdar, Muhammad Rizwan. 2010. Pay Benefits And Workplace Milieu Effecting Job Satisfaction Level Of University Teachers: A Case Study Of Punjab University. International Journal of Asian Social Science 2(10):1815-1831. journal homepage:

http://www.aessweb.com/journaldetail.php?id=5007. 
Odunlade, R.O. 2012. Managing Employee Compensation and Benefits for Job Satisfaction in Libraries and Information Centres in Nigeria Digital Commons. University Of Nebraska. (Online)

Ogaboh, Agba, A. M., Nkpoyen, Festus,Ushie, E. M. 2010. Career development and employee commitment in industrial organisations in Calabar, Nigeria. American Journal Of Scientific And Industrial Research $\odot$ 2010, Science HuB, Http://Www.Scihub.Org/Ajsir

Okpara, J. O. 2004. Personal characteristics as predictors of job statisfaction:An explanatory study of IT managers in developing country. Information Technology \& People, 17, 327-338.

Riveros, Andrea M. Moscoso. Tsai, Ted Shir-Tau. 2011. Career Commitment and Organizational Commitment in for-Profit and non-Profit Sectors. Int. J. Emerg. Sci., 1(3), 324-340, September 2011. ISSN: 22224254@ IJES.

Robbins, Stephen P. Judge, Timothy A. 2006. Perilaku Organisasi. Edisi kesepuluh. Gramedia, Jakarta.
Sinclair, R.R., Tucker, J.S., Cullen, J.C., \& Wright, C. 2005. Performance Differences Among Four Organizational Commitment Profiles. Journal of Applied Psychology 90 (6), 1280-1287.

Shujaat, Sobia. Sana, Saira.Aftab, Faisal. Ishtiaq Ahmed. 2013. Impact of Career Development on Employee Satisfaction in Private Banking Sector Karachi. Journal of Management and Social Sciences Vol. 9, No. 2, (2013) 01-08.

Travis G Worrell, T. G. 2004. School Psychologist"s Job Satisfaction; Ten Years Later. Unpublished doctoral dissertation. Virginia Polytechnic Institute and State university. COPYRIGHT 1999 Heldref Publications.

Trochim, W.M.K. 2006. Research Methods Knowledge Base. http://en.wikipedia.org

Vandenberghe and Trembley. 2008. The Role of Pay Satisfaction and Organizational Commitment in Turnover Intention: A Two Sample Study. Journal of Business and Psychology. Vol 22 No 3. Pp 275286.

Weng, Qingxiong, McElroy, James C., Morrow, Paula C., Liu, Rongzhi. 2010. The relationship between career growth and organizational commitment. Journal of Vocational Behavior. journal homepage: www.elsevier.com/locate/jvb 